\title{
Partido de Representação Popular
} estrutura interna e inserção eleitoral (1945-1965)

O Partido de Representação Popular (PRP) foi constituído no final de 1945, reunindo integralistas sob a liderança de Plínio Salgado. ${ }^{1}$ A trajetória deste partido e o papel político por ele desempenhado têm sido objeto de poucas investigações acadêmicas. Na maioria das vezes o movimento integralista brasileiro é lembrado por sua intervenção na década de 1930, que se deu através da Ação Integralista Brasileira (1932-1937), com seus desfiles públicos, sua simbologia e ritualística e sua organização fascistizante. ${ }^{2} \mathrm{~A}$ intervenção integralista, no entanto, não se restringe a esse período. Ao contrário, teve continuidade, com diferentes características e formas de organização diversas, nas décadas seguintes, seja atuando clandestinamente durante o período do Estado Novo (1938-1945), seja através da intervenção do PRP, entre 1945 e 1965, seja agindo no interior da Aliança Renovadora Nacional (ARENA), entre 1965 e 1979, ou do partido que a sucedeu nas décadas seguintes, com suas diferentes denominações (Partido Democrático Social; Partido Progressista Renovador; Partido Progressista Brasileiro; Partido Progressista), ou ainda através da fundação de pequenos grupos neointegralistas nas décadas de 1980, 1990 e mesmo recentemente. ${ }^{3}$

O processo de constituição do PRP é discutido em Calil (2001 e 2005a).

Ver a respeito: Trindade (1974); Chasin (1999); Cavalari (1999); Vasconcelos (1979); e Chauí (1978).

3 Os principais grupos integralistas que atuam hoje são a Frente Integralista Brasileira (FIB) e o Movimento Integralista e Linearista do Brasil (MIL-B). Com relação à atuação recente de neointegralistas, ver o trabalho de Carneiro (2007). 
O PRP foi fundado em setembro de 1945 e manteve-se atuante até o cancelamento dos registros partidários, imposto através do Ato Institucional número 2, em 1965. Ainda assim, grande parte das obras que tratam do processo político brasileiro no período entre 1945 e 1964 sequer menciona sua existência e, dentre aquelas que o referenciam, a maior parte faz uma apresentação superficial, destacando traços caricatos e tratando-o como irrelevante - o que se justificaria pela sua reduzida expressão eleitoral. Um exemplo é o tratamento dado por Edgard Carone:

O Partido de Representação Popular torna-se cada vez mais um marginal político dentro do contexto brasileiro, embora o toque megalomaníaco de seu Chefe, auxiliado por pequeno grupo de fiéis - alguns do passado, outros do presente - tente demonstrar que ele e seu partido representam as forças vitais no combate ao comunismo e à deturpação dos valores da sociedade brasileira. Seu papel político é tão secundário, no entanto, que em nenhum momento as classes dominantes, nem o Exército, tentam atraí-lo aos movimentos conspiratórios, como em 1955 e 1964. (CARONE, 1985, p. 332) ${ }^{4}$

Tal avaliação parece-nos insuficiente e em grande medida incorreta, se consideramos os resultados eleitorais obtidos pelo PRP no contexto de sua estratégia política, da base social por ele mobilizada, das características de seu projeto, e também se considerando a configuração nacional do partido. Além disso, muitas vezes pesquisas concentradas exclusivamente em dados eleitorais não captam integralmente a inserção eleitoral do PRP, tendo em vista que em grande parte das ocasiões ele apresentou candidatos no interior de coligações e em algumas situações até mesmo sob a legenda de outros partidos, mediante acordo interpartidário, o que determina um subdimensionamento do contingente eleitoral deste partido.

A estruturação do PRP viabilizou a organização ativa de expressiva parcela da militância integralista, sob controle de Salgado, constituindo um instrumento eficaz para sua intervenção no processo político. Para isto, foi necessária a estruturação nacional do partido, dotando-o de uma vasta rede de diretórios municipais, diretórios regionais em todos os estados e

\footnotetext{
4 Argumentamos em Calil (2005b) que, ao contrário do proposto por Carone, o movimento integralista desempenhou relevante papel no Golpe de 1964, participando da conspiração golpista, das articulações políticas que a precederam, da organização das marchas contra João Goulart e da disseminação do anticomunismo no parlamento e em atividades públicas.
} 
convenções periódicas, garantindo a mobilização permanente da militância integralista, ainda que ela tenha se dado em patamares inferiores à obtida pela AIB nos anos 1930. A hipótese central que orienta a investigação aqui apresentada é que desta forma o PRP se constituiu como partido nacional, no que se refere ao seu projeto, a sua estruturação regional e também aos resultados eleitorais obtidos.

Esta investigação utilizou como principal fonte - além dos dados eleitorais publicados pelo Tribunal Superior Eleitoral (TSE) - a documentação partidária do PRP, consultada nos dois principais acervos que se tem conhecimento: o Arquivo Público e Histórico de Rio Claro, que reúne toda a documentação pessoal de Plínio Salgado e, com ela, a documentação do Diretório Nacional do PRP; e o Centro de Documentação sobre a Ação Integralista Brasileira e o PRP ${ }^{5}$, que reúne a documentação do Diretório Regional do Rio Grande do Sul. Também foram utilizadas correspondências, circulares e diretrizes; assim como foram consultados os principais jornais do PRP (Idade Nova e A Marcha, de circulação nacional, e Boletim do PRP, editado no Rio Grande do Sul), os livros de Plínio Salgado e depoimentos orais de ex-integrantes daquele partido.

\section{A organização partidária e a constituição dos diretórios}

As dificuldades enfrentadas para a estruturação partidária em um país continental e federativo como o Brasil são analisadas pelo cientista político Gláucio Soares. De acordo com ele:

A organização dos partidos não nasce feita: um país federativo requer diretórios regionais (estaduais); um país com municípios requer uma extensa rede de diretórios municipais. A fundação de diretório é apenas o início da organização de um partido, que é um processo longo. A estruturação de um partido implica a criação de vínculos com os meios de comunicação de massa, com organizações civis (como os sindicatos e as religiões organizadas), além da criação de diretórios. (SOARES, 2001, p. 65)

O resultado da eleição de 1945, na qual PSD e UDN elegeram juntos $82 \%$ dos deputados federais - bem mais do que em qualquer eleição posterior - se deve em grande parte ao fato de que eram os únicos partidos que

Estes arquivos serão referenciados a partir daqui pelas suas siglas, respectivamente APHRC e CDAIBPRP. Este último acervo atualmente encontra-se sob a guarda da PUC-RS. 
contavam com uma ampla estrutura organizacional, abarcando todos os estados e a grande maioria dos municípios. Para o PRP, constituído poucos dias antes das eleições, a defasagem organizacional em 1945 era dramática, sendo esse um dos principais fatores explicativos do péssimo resultado eleitoral alcançado pelo partido naquela eleição, quando elegeu apenas um deputado federal e obteve pouco mais de 130.000 votos em todo o país, o que corresponde a 2,3\% dos votos, seu pior percentual em âmbito nacional em eleições parlamentares durante toda sua trajetória. Após as eleições de 1945, o partido definiu como objetivo central a ampliação de sua rede de diretórios estaduais e municipais, em um processo de interiorização de sua estrutura organizativa. Em 1946, inúmeras excursões - denominadas pelos integralistas de "bandeiras" - percorreram centenas de municípios com esse objetivo, promovendo comícios, e realizando propaganda partidária. Em julho daquele ano, uma correspondência de Jayme Ferreira da Silva a Plínio Salgado (que permanecia autoexilado em Portugal, retornando ao Brasil apenas em setembro de 1946) relatava o avanço organizativo:

O interior vai sendo sacudido. Nosso escritório já conseguiu ligação com mais de 600 localidades e só em uma expedição, no princípio deste mês, foram remetidos pacotes num total de 1046 quilos, contendo milhares de exemplares da Carta-Diretiva de 31 de julho, além de outros prospectos. Em Minas, fundam-se escolas dentro dos diretórios e estas crescem com a adesão de novos adeptos. Em Santa Catarina, nossa gente sai da letargia. O Rio Grande está magnífico. O Paraná foi acordado pela centelha de nossa propaganda. São Paulo tem melhorado muito. A Bahia, qual gigante da nossa tradição, começa a esticar os braços para repetir a "palavra nova dos novos tempos". Pernambuco foi despertada há 45 dias, pelo Mayrink que lá esteve e que logrou êxito inédito, aceitando e abafando os apartes dos nossos velhos adversários marxistas. Do Ceará chegam também notícias auspiciosas com o nosso Barbosa, que de lá regressou na última semana. Goiás nos enviou um emissário. O Pará e o Maranhão também estão de pé. (Correspondência de Jayme Ferreira da Silva a Plínio Salgado, 21/7/1946 - APHRC - PiPrp 21/7/1946)

A citação indica que o processo de organização abarcava inúmeros estados, de todas as regiões do país. Para facilitar a formação de diretórios municipais, sua constituição era permitida com apenas 3 integrantes, nos postos de Presidente, Secretário e Tesoureiro (PRP, 1945, p. 27), dispensando-se, provisoriamente, até mesmo a necessidade de contar com sede 
partidária própria (Boletim do PRP, Porto Alegre, 30/6/1946, p. 2). Além disso, estimulava-se a formação de subdiretórios nos distritos rurais (PRP, 1945, p. 29). Ao final de 1946, o partido divulgou que teria "quase oitocentos diretórios já instalados", levando o jornal Idade Nova a proclamar - com evidente exagero - que o partido chegaria às próximas eleições "na situação de grande partido, podemos dizer, mesmo, na situação de um dos 'big fours' do imediato futuro político nacional" (Idade Nova, Rio de Janeiro, 19/10/1946, p. 1 e 5). ${ }^{6}$ A II Convenção Nacional do PRP, realizada em outubro de 1946, contou com a presença de delegados de todos os estados, além do Distrito Federal e do território do Acre (Idade Nova, Rio de Janeiro, 2/11/1946, p. 7), o que evidencia que a estrutura partidária já havia se ampliado significativamente. No ano de 1949, o partido lançou a "Campanha Nacional dos 1000 núcleos" (Ofício da Secretaria Estadual de Arregimentação Estudantil do Rio Grande do Sul aos diretórios municipais - 7/7/1949 - CDAIBPRP), visando à estruturação de mil diretórios municipais, objetivo que, a julgar pela informação apresentada no jornal partidário, teria sido alcançado no ano seguinte, quando o partido contaria com 1.004 diretórios municipais e 593 diretórios distritais (Idade Nova, Rio de Janeiro, 1/6/1950, p. 1). Entre 1947 e 1949, Salgado percorreu o país, em diversas caravanas, formando diretórios e promovendo atividades públicas. Um panfleto de divulgação da programação da caravana na cidade de Poções (BA), em 1949, ilustra como se desenvolviam essas atividades:

Em primeiro lugar, pede-se ao Comércio a fineza de cerrarem as suas portas durante o dia 8, para que todos, em união fraterna, possam tomar parte em todas as homenagens programadas. A cidade será despertada por uma salva de 21 tiros na madrugada do dia 8 e algumas bombas anunciarão a entrada da "Bandeira El Rei D. João III", que percorre os sertões da Bahia, chefiada pelo Sr. Plínio Salgado. Convida-se o povo da cidade, sem exceção de cor, credo religioso ou partidarismo político, para reunir-se nas escadarias da Igreja Católica, no dia 8 e 9 horas da manhã, a fim de receber com uma salva de palmas a "Bandeira El Rei D. João III". Após a missa, enquanto o sr. Plínio Salgado paraninfa o batizado de uma criança, o povo se transportará ao local da construção da nova Igreja, onde terá a oportunidade de ouvir a palavra do De-

\footnotetext{
6 As projeções eleitorais divulgadas pelo partido eram sempre exageradamente inflacionadas, com vistas a dois objetivos principais: estimular os integralistas nas campanhas eleitorais e valorizar o capital político do PRP nas negociações que envolviam a formação de coligações com outros partidos. Ver a respeito, Calil (2001, p. 191-195).
} 
putado Federal Goffredo Telles e outros oradores (...). Logo após o almoço, partirá a "Bandeira" para a visita às minas de amianto (...). Não faltará transporte desta cidade para este aprazível e utilíssimo passeio (...). De regresso do passeio, às 6 horas, no Cinema local, o Sr. Plínio Salgado fará a "Crônica da Ave Maria", que será irradiada para toda a cidade. (...). Para a sessão solene das 20 horas, pede-se ao Ilustre Sr. Delegado de Polícia e o Sr. Sargento Instrutor do Tiro de Guerra, o necessário controle para que as famílias se coloquem em primeiro lugar no Salão da conferência, pois receamos que o prédio seja pequeno para conter todo o povo. (Ao povo de Poções. Panfleto - APHRC-Pprp 7/4/1949/1)

Evidencia-se, assim, a diversidade de atividades realizadas na divulgação do partido e busca de expansão de sua estrutura organizativa. Embora esta tenha se desenvolvido em todo o país, se deu de forma bastante desigual, pois os integralistas tiveram maiores dificuldades para estruturar o PRP nos estados mais atrasados economicamente e com menor população, situados na região Nordeste e, principalmente, no Norte e Centro-Oeste. Um levantamento produzido pelo Departamento de Controle e Estatística do PRP revela que $72 \%$ dos diretórios municipais em funcionamento no ano de 1948 (ou seja, 444 de um total de 618 diretórios constituídos) localizavamse em apenas oito estados: São Paulo (91), Rio Grande do Sul (64), Minas Gerais (61), Bahia (57), Ceará (49), Pernambuco (44), Rio de Janeiro (41) e Paraná (37). Os demais se localizavam em Santa Catarina (29), Espírito Santo (29), Pará (19), Goiás (19), Rio Grande do Norte (16), Mato Grosso (16), Maranhão (15), Paraíba (10), Piauí (9), Amazonas (6) e Sergipe (6) (Idade Nova, Rio de Janeiro, 21/10/1948, p. 4). Um relatório produzido em 1949 pelo dirigente perrepista Abel Rafael Pinto, incumbido de inspecionar as atividades do partido em seis estados do Norte e Nordeste, evidencia as dificuldades e problemas enfrentados pelo partido: no Pará o partido teria somente 4 diretórios municipais em funcionamento; no Maranhão, teria sido muito abalado pela deserção de seu único deputado estadual (Padre Joel Barbosa), ficando reduzido também a apenas $4 \mathrm{DMs}$ em funcionamento; no Piauí, mantinham-se em funcionamento apenas 2 DMs; no Rio Grande do Norte, o partido teria enfrentado um grande tumulto em um comício; na Paraíba, enfrentaria a carência de militantes e de recursos; e somente no Ceará haveria algum avanço na estruturação partidária, e ainda assim ameaçada por um conflito em torno da indicação do candidato a deputado federal (Relatório de Abel Rafael Pinto, 23/3/1949 - APHRC-Pprp 23.3.1949/1). 
Os resultados eleitorais obtidos nesses estados, como será discutido, foram igualmente bastante modestos, inferiores à média nacional, o que reforça a correlação entre estruturação partidária e obtenção de resultados eleitorais.

\section{As dinâmicas de funcionamento partidário}

Através das correspondências entre as instâncias partidárias, é possível tomar conhecimento de algumas atividades desenvolvidas pelos diretórios estaduais ou municipais, ou ainda, das atividades que o Diretório Nacional deles esperava. No que se refere aos diretórios estaduais, eles periodicamente prestavam informações respondendo a extensos questionários remetidos pelo Diretório Nacional, os quais indagavam quanto às atividades desenvolvidas. Tais relatórios mencionam a realização de "sessões doutrinárias", a promoção de concentrações regionais de militantes, a realização de excursões de propaganda, a promoção de atividades voltadas aos estudantes, a edição de folhetos, boletins, cartazes e materiais de propaganda, a realização de programas de rádio e a promoção de eventos voltados às mulheres. Em um ofício enviado aos diretórios municipais, Plínio Salgado listava algumas atividades que estes deveriam realizar, dentre as quais a promoção semanal de reuniões doutrinárias; a organização e manutenção de uma biblioteca na sede partidária; a promoção de comemorações públicas das datas nacionais; o exercício da "maior vigilância possível sobre os comunistas locais", com a sistemática remessa ao Diretório Nacional de seus nomes, profissões e cargos que ocupavam; e a realização cotidiana de propaganda partidária (Ofício do Presidente do Diretório Nacional do PRP Plínio Salgado aos Diretórios Municipais, 20/3/1951 - CDAIBPRP). Seria necessário um estudo sistemático da vasta documentação disponível relativa aos diretórios municipais para uma avaliação mais precisa da intensidade com que estas atividades eram realizadas. ${ }^{7}$ Levando em conta a clássica distinção entre partido de massas e partido de quadros, proposta por Maurice Duverger (1970), percebe-se que o PRP, ainda que não tenha chegado a se caracterizar como um partido de massas - até pela sua avaliação negativa das massas, tidas como incapazes e amorfas - também não se restringiu aos limites estritos de um partido de quadros, pois realizou atividades periódicas fora dos períodos eleitorais e

O principal estudo disponível com esta perspectiva (CARDOSO, 2009) trata da implantação do PRP no Rio Grande do Sul, discutindo a constituição da sua máquina partidária e as ações desenvolvidas pelo Diretório Regional naquele estado. 
pretendeu mobilizar e organizar seus adeptos de forma permanente, no que teve um êxito relativo. É certo que não logrou manter o grau de permanente mobilização alcançado pela Ação Integralista Brasileira na década de 1930, mas ainda assim conseguiu promover a realização de inúmeras atividades partidárias fora dos períodos eleitorais, não se restringindo às atividades parlamentares e executivas, no que se distinguia claramente dos principais partidos do período, cuja estruturação era quase exclusivamente voltada aos processos eleitorais.

Os Estatutos do PRP, aprovados em setembro de 1945, foram alterados sete vezes até 1964. Ainda assim, à exceção das reformas de 1946 e 1947, as demais alterações foram superficiais, produzindo apenas alterações pontuais. A reforma estatutária de 1946, realizada durante a II Convenção Nacional, foi conduzida diretamente por Plínio Salgado, modificando profundamente a estrutura partidária e fortalecendo enormemente a Presidência Nacional, no mesmo momento em que o próprio Salgado assumia o cargo, no qual permaneceria até o encerramento das atividades partidárias, em 1965.

No que se refere aos órgãos dirigentes, o Estatuto de 1945 previa um Diretório Nacional de cinco membros que se reuniria semanalmente, subordinados a um Conselho Nacional de 12 membros que se reuniria mensalmente, ambos eleitos pela Convenção Nacional (PRP, 1945). Com a reforma de 1946, o Diretório Nacional passou a ter 15 membros e reuniões mensais; o Conselho Nacional passou a ter 35 membros; e foi criada a Comissão Nacional de Orientação Política, com quatro membros livremente indicados pelo Presidente Nacional do Partido e diretamente subordinados a ele. Este novo órgão passou a reger a vida diária do partido, e as principais questões em tramitação no Diretório Nacional deviam ser previamente avaliadas por ela (PRP, 1946). Ainda assim, esta estrutura durou poucos meses, sendo substituída por outra ainda mais centralizada.

A segunda reforma estatutária ocorreu em março de 1947, durante a III Convenção Nacional, convocada especialmente para tal fim, e extinguiu a Comissão Nacional de Orientação Política constituindo em seu lugar dez Secretarias Nacionais: Arregimentação Eleitoral; Propaganda; Finanças; Assistência Social; Arregimentação Feminina; Arregimentação Trabalhista; Arregimentação Estudantil; Cultura Artística; Educação Moral, Cívica e Física; e Estudos e Planos Governamentais, cujos secretários eram livremente nomeados pelo Presidente Nacional e diretamente subordinados a ele (PRP, 
1947). As reformas seguintes ocorreram na IX Convenção Nacional, em 1951, na XIII, em 1956, na XIV, em 1957, e na XVI, em 1959. ${ }^{8}$ A reforma de 1956 aumentou o número de componentes do Diretório Nacional para 45 membros e criou um Conselho Nacional constituído pelos presidentes dos Diretórios Regionais e pelos deputados estaduais, além de acirrar a disciplina partidária (A Marcha, Rio de Janeiro, 27/4/1956, p. 1). ${ }^{9}$ A reforma de 1959 estabeleceu a obrigatoriedade de realização de duas reuniões mensais dos Diretórios durante o período em que estivessem reunidas as Câmaras Federal, Estaduais e Municipais e facilitou a punição dos militantes em atraso com a contribuição financeira (PRP, 1959). Finalmente, em 1961, os Estatutos foram novamente alterados, passando o Diretório Nacional a ter um número variável de componentes, de 15 a 45, incluindo como membros natos os representantes no Congresso Nacional; extinguindo o Conselho Nacional e criando em seu lugar o Conselho Político, composto por 14 membros nomeados pelo Presidente do Diretório Nacional e a ele subordinados; e também o Conselho Consultivo, reunindo os parlamentares do partido, os presidentes dos diretórios regionais e outros membros indicados pelo Presidente do Diretório Nacional. Também passou a permitir a eleição de integrantes de um Diretório para outro, desde que não ocupassem funções específicas (PRP, 1961). É interessante observar que em todas as versões anteriores dos estatutos (entre 1945 e 1959) era vetada a participação de membros das direções regionais e municipal no Diretório Nacional, ao contrário do que ocorria, por exemplo, no PSD, cujo Diretório Nacional era composto exatamente pelos presidentes dos diretórios regionais. Esta opção da liderança perrepista acentuava a hierarquia do partido e colocava o Diretório Nacional como uma instância claramente separada e acima dos diretórios regionais, o que implica em altíssimo grau de centralização, sob controle do Presidente Nacional.

Outro aspecto relevante é que em todas as versões dos Estatutos permaneceram definidos os cinco "fundamentos" do partido:

8 PRP - Estatutos. Aprovados pela IX Convenção Nacional. Mimeografado (CDAIBPRP). Partido de Representação Popular - Estatutos. Aprovados pela XII Convenção Nacional. Mimeografado (APHRC-FPS 067.001.001); Partido de Representação Popular - Estatutos. Aprovados pela XIV Convenção Nacional. Mimeografado (APHRC-FPS 067.001.002).

9 Embora tendo sido criado pela Convenção, ao que parece este órgão não chegou a funcionar, sendo substituído por um Conselho Político Nacional, bem mais restrito, composto apenas pelos deputados federais do partido (A Marcha, Rio de Janeiro, 14/6/1957, p. 1 e 6). 
I - O conceito espiritualista de vida, em conformidade com as tradições do povo brasileiro, e em oposição a todas as ideologias materialistas; II - O princípio da intangibilidade da pessoa humana e, conseqüentemente, os princípios democráticos de liberdade e justiça, assegurada, para todos os cidadãos, a igualdade de direitos e deveres perante a lei; III - A afirmação da unidade orgânica da Pátria, que se formou e se perpetuará pelo entendimento e esforço conjugados de todos os cidadãos, sem distinção de raças ou classes; IV - O engrandecimento moral, intelectual e econômico da Nação, garantida a educação de todos, a melhoria das condições de vida dos trabalhadores e o amparo aos elementos produtores; $\mathrm{V}$ - O combate contra todas as ideologias totalitárias, inimigas da dignidade do homem, da soberania natural e da harmonia entre os povos. (PRP - Estatutos. Aprovados pela III Convenção Nacional. Mimeografado (APHRC-FPS 016.008.001) $)^{10}$

Em 1962, foi acrescentado um sexto ponto, “o aperfeiçoamento, pelos meios constitucionais, do sistema representativo vigente, fundamentado no sufrágio universal e no pluripartidarismo, complementando-o, também, através da representação dos grupos econômicos, profissionais e culturais de caráter corporativo" (PRP, 1962, p. 2). Esta retomada revela a retomada explícita da defesa do corporativismo, que fora extremamente relevante no ideário integralista dos anos 1930 e havia sido omitida durante a maior parte da trajetória do PRP - omissão que se explica pelo contexto hostil a perspectivas fascistizantes instaurado no imediato pós-guerra.

As secretarias criadas em 1947 tiveram grande relevância na estrutura partidária e, de acordo com os Estatutos, deviam ter existência regular também no âmbito dos estados e dos municípios. ${ }^{11}$ A perspectiva de Salgado era constituir uma organização bastante capilarizada, com capacidade de rivalizar com o Partido Comunista:

$\mathrm{O} \mathrm{PCB}$, atuando dentro dos princípios rígidos do leninismo, está transformando uma minoria organizada numa potência capaz de vencer e dominar um povo. Assim, se não quisermos ser cúmplices, precisamos dar ao nosso partido também uma organização

\footnotetext{
10 A redação destes "fundamentos" nos Estatutos de 1945 era levemente diversa.

${ }^{11}$ É muito difícil dimensionar em que medida esta diretriz se efetivou na prática, pois existem poucos estudos específicos. Alguns indícios sugerem grandes dificuldades. Em relatório apresentado à Convenção Estadual do PRP no Paraná em 1949, o secretário estadual do partido lamentava que apenas dez diretórios municipais tinham nomeado um Secretário Municipal de Arregimentação de Estudantes e que somente três teriam nomeado uma Secretaria Municipal de Arregimentação Feminina. In: Relatório do Secretário Estadual à Convenção Estadual PRP-PR 1949 (APHRC-FPS 015.002.001).
} 
capaz de se opor àquela máquina subversiva, que é a mais perfeita organização atual entre nós. (Boletim do PRP, Porto Alegre, 4/2/1946, p. 3)

A documentação partidária disponível permite apontar que, enquanto uma parte destas secretarias funcionou com grande regularidade, outras tiveram pouca expressão. Algumas, como Finanças, Propaganda e Arregimentação Eleitoral, em virtude da imprescindibilidade de seu funcionamento para os objetivos eleitorais do partido, eram objeto de maior preocupação. Já aquelas voltadas à formação política e doutrinação tendiam a ficar em segundo plano. ${ }^{12}$ A Secretaria Nacional de Educação Moral, Cívica e Física tinha por finalidade "incutir na mocidade o mais elevado amor à Pátria, o culto das virtudes públicas e particulares, aprimorando nos jovens os seus dotes intelectuais e físicos, tudo subordinado a uma concepção de existência e dos superiores destinos humanos" (SECRETARIA NACIONAL DE EDUCAÇÃO MORAL, CÍVICA E FÍSICA, s./d.), através da formação de bibliotecas, da promoção de atividades físicas e da criação de escolas, cursos e conferências relacionados a comemorações e festas cívicas e a assuntos políticos e sociológicos. A Secretaria Nacional de Cultura Artística deveria “incentivar, difundir, criar e controlar a parte artística e cultural do Partido de Representação Popular" (Boletim do PRP, 31/10/1947, p. 3), mas teve atuação efetiva em pouco estados e municípios. A Secretaria Nacional de Arregimentação Feminina tinha por finalidade promover ações assistencialistas, criar escolas de alfabetização e de "boas maneiras", puericultura, taquigrafia, culinária, economia doméstica, corte e costura e outros, realizar reuniões doutrinárias semanais, confeccionar trabalhos manuais e vendê-los para arrecadar fundos ao partido, promover festivais artísticos, literários e musicais, e realizar festas de Natal, Páscoa, dia dos pais e dia das mães (Diretiva de Plínio Salgado aos diretórios regionais, 17/10/1953). Sua dinâmica se vinculava com o papel subordinado preconizado pelos integralistas para as mulheres. A Secretaria Nacional de Arregimentação Trabalhista deveria "instruir e orientar seus

12 O relativo fracasso de algumas destas secretarias parece ter sido um dos motivos pelos quais na década de 1950 os integralistas passaram a tentar arregimentar politicamente alguns setores, como estudantes e trabalhadores, fora do âmbito partidário, em entidades formalmente independentes. A mais importante dentre essas iniciativas foi a constituição da Confederação dos Centros Culturais da Juventude, que chegou a congregar ao menos 320 centros culturais. Ver a respeito Calil (2005a, p. 457-469). Embora tais organizações não fossem formalmente vinculadas ao PRP, eram diretamente subordinadas a Plínio Salgado. 
associados e simpatizantes sobre todos os problemas sociais, econômicos e políticos referentes às massas trabalhadoras" (Idade Nova, Rio de Janeiro, 28/10/1948, p. 4). A disputa pelo operariado, em oposição aos comunistas, era seu principal objetivo, para o que deveria "prestar às classes trabalhistas, todo o apoio de que necessitam para a defesa de suas justas reivindicações, libertando-as da humilhante dependência de falsos líderes ou agentes de forças antinacionais, que capciosamente, dia a dia, vêm agravando seus problemas" (Boletim do PRP, Porto Alegre, 31/10/1947, p. 3). No entanto, o próprio Secretário Nacional, Nelson Chiurco, admitia, em 1950, que "o partido está atrasadíssimo na sua campanha no setor trabalhista" e que, a despeito de ter anunciado a pretensão de "criar um grande movimento trabalhista no PRP", o partido teria atraído poucos operários, não tendo conseguido constituir uma forte fração sindical (Circular do Secretário Nacional de Arregimentação Trabalhista Nelson Chiurco aos Diretórios Regionais do PRP, 24/2/1950). A Secretaria Nacional de Assistência Social tinha por finalidade "exercer, em todo o território nacional, serviços de assistência, educação e cooperação social, em benefício dos associados do PRP e de toda a população em geral" (SECRETARIA NACIONAL DE ASSISTÊNCIA SOCIAL, s./d), estimulando "a organização de instituições privadas, de assistência social (ambulatórios, creches, lactários, casas de saúde, maternidades, asilos, escolas de costura, arte, culinárias, enfermagens, dispensários, cooperativas, pensionatos, enfim, sociedades de beneficência) que possam pelo menos atenuar os efeitos da miséria que campeia em todas as cidades do Brasil" (Idade Nova, Rio de Janeiro, 30/9/1948, p. 5 $)^{13}$. A finalidade da Secretaria Nacional de Arregimentação Estudantil seria "arregimentar os estudantes filiados ao PRP, estimulando entre eles o gosto pela pesquisa dos fatos sociais e dos fenômenos econômicos e políticos brasileiros, de sorte a formar-lhes elevado espírito público" (SECRETARIA NACIONAL DE ARREGIMENTAÇÃO DE ESTUDANTES, s./d.) A Secretaria promovia regularmente cursos e palestras relativos a temas políticos e doutrinários e, em julho de 1948, organizou o I Congresso dos Estudantes Populistas, em Campinas, reunindo mais de 700 estudantes (Idade Nova, Rio de Janeiro, 8/7/1948, p. 1 e 6). ${ }^{14}$ A Secretaria de Estudos

\footnotetext{
${ }_{13}$ A utilização do assistencialismo como estratégia de expansão partidária e de qualificação de eleitores, através da manutenção de escolas de alfabetização, bem como a promoção de campanhas de coleta e distribuição de gêneros, é discutida em Calil (2001, p. 189-191).

${ }^{14}$ O Congresso teve a participação, dentre outros, dos deputados estaduais paulistas Oliveira Costa (líder do PSD), Auro Moura Andrade (líder da UDN), Cunha Lima (líder do PTB), Osny Silveira (sublíder da
} 
e Planos Governamentais tinha como objetivo formar quadros partidários para a intervenção no parlamento e nos governos, mas produziu pouca documentação, e os estudos e planos por ela supostamente produzidos não vieram a público. Bem mais relevante foi a atuação da Secretaria Nacional de Arregimentação Eleitoral, visando "incrementar, organizar e superintender os serviços de qualificação eleitoral e arregimentação política nos setores nacional, estaduais, municipais e distritais" (SECRETARIA NACIONAL DE ARREGIMENTAÇÃO ELEITORAL, s./d.). Já em 1946, o partido seguia um planejamento de cadastro eleitoral, prevendo uma organização secreta e confidencial de alistamento de eleitores, segundo a qual cada militante ficava responsável por acompanhar determinado número de eleitores (Instruções de Arregimentação Eleitoral - Confidencial. 27/6/1946). O PRP promoveu ainda um curso de formação de "líderes" e organizou de equipes de trabalho, para as quais os militantes eram convocados e inseridos em uma estrutura claramente hierárquica:

Cada companheiro deve desde já assumir o cargo de Sub-Monitor, chefe de 5 eleitores. Se o sub-monitor tiver capacidade para ser o Mentor ou Orientador de 10 eleitores, será designado Monitor. Por isso que, 20 Sub-Monitores (cada um com seus 5 eleitores) ou 10 Monitores (cada um com seus 10 eleitores), formarão uma Bandeira, sob a orientação de um Bandeirante (Instruções de Arregimentação Eleitoral, s./d).

Pelas normas estabelecidas, ainda, os monitores eram obrigados a visitar todos os eleitores pelo menos uma vez por semana, devendo ser todos eles novos para o partido, não constando das listas de simpatizantes. A existência desse planejamento, ainda que não existam meios para investigar sua eficácia, revela o objetivo de impor uma disciplina muito rigorosa sobre os militantes, uma concepção claramente autoritária da política e a perspectiva de exercer um controle absoluto sobre os eleitores. Mais do que isto, é expressão clara da concepção hierárquica e hierática dos integralistas e de sua pretensão em formar militantes adestrados à obediência, bem como dirigentes intermediários preparados para obedecer a seus superiores e se impor perante

UDN), Cunha Bueno (PSD) e Luis de Mattos (PTB), além dos parlamentares do PRP; e recebeu moções de congratulações unanimemente aprovadas pelas Assembleias Legislativas do Rio de Janeiro e São Paulo. Cf. Ata do Diretório Nacional e do Conselho Nacional, 13/7/1948. Livros de Atas do Diretório Nacional e do Conselho Nacional (APHRC-FPS 021.005.005). Também na Câmara Federal foi apresentado um requerimento de felicitações, com assinaturas de parlamentares do PSD, UDN, PTB, PSP e PR. 
os militantes de base, inclusive utilizando-se de táticas de cunho militar, como a suspeição permanente, o exercício do controle e a imposição de sua posição hierárquica.

Outras secretarias nacionais foram posteriormente criadas, dentre as quais a Secretaria Nacional de Arregimentação de Marítimos, formada em 1948, visando "propagar entre os homens do mar a doutrina político-social" (PRP, 1948); e a Secretaria Nacional de Assuntos Pessoais, criada em março de 1959 "para desafogar o Chefe Nacional da verdadeira onda de pedidos os mais variados e relacionados com todas as repartições públicas e até particulares, que de todos os pontos do país lhe chegam diariamente" (A Marcha, Rio de Janeiro, 17/4/1959, p. 4), e com as seguintes finalidades:

a) encaminhar às autoridades e personalidades competentes os pedidos de correligionários relativos a nomeações, promoções, transferências, reintegrações, readmissões, comissões e outros; b) promover internamento em hospitais, admissão em asilos e escolas, obtenção de bolsas de estudo, reconduções a estados ou cidades de origem dos solicitantes, exames médicos e medicamentos a indigentes; c) diligenciar no sentido de conseguir empregos no comércio, na indústria, em escritórios profissionais ou na agricultura aos correligionários, ou recomendados por estes, que os pedirem; d) dar assistência jurídica nos casos necessários (...); e) acompanhar e fazer andar, nos Ministérios, Autarquias e mais Repartições, os papéis daqueles que solicitarem intervenção e auxílio; f) visitar os enfermos e encarcerados (...); g) representar o Partido e o Chefe em enterros, missas, festas de aniversário, bodas de prata e ouro, banquetes, atos de formatura e cerimônias religiosas, sessões solenes, recepções, inaugurações, conferências e congressos; h) dar audiências para atender a solicitantes e interessados e manter em dia a correspondência com os solicitantes dos Estados; i) articular-se com a Bancada do Partido na Câmara Federal, com o Senador ou Senadores do Partido, com o Vereador ou Vereadores do Distrito Federal e com os presidentes dos Diretórios Regionais (Portaria de Criação da Secretaria Nacional de Assuntos Pessoais, assinada por Plínio Salgado, 28/3/1959).

A criação da Secretaria de Assuntos Pessoais indica que o vetor ideológico não era o único responsável pelo crescimento partidário. O caráter abertamente clientelista do conjunto das atividades previstas como finalidades da Secretaria, bem como a evidente utilização da influência dos postos ocupados pelo partido, diretamente mencionada nos itens (a), (c), (e), (h), e (i) demonstram que o partido pautava seu relacionamento com uma parcela de 
seus eleitores e potenciais eleitores pela concessão de vantagens e favores, colocando em segundo plano os aspectos doutrinários, ideológicos e políticos. A criação da Secretaria era justificada pelo fato de que Salgado estaria com "594 casos de pedidos de nomeações, transferências, promoções, etc." (Correspondência de Plínio Salgado a João Plácido de Lima, 26/3/1959 - APHRCPprp 59.03.26/5). ${ }^{15}$ A nova secretaria era composta de cinco departamentos: Assuntos Políticos, Colocações, Assistência, Expediente, e Atividades Sociais. De fato, encontramos nas correspondências de Plínio Salgado, anteriores e posteriores à data da criação da secretaria, centenas de correspondências, com pedidos de ajuda, de livros, de dinheiro, de empregos, de internação, de nomeação em cargos públicos, de alteração de resultado de concursos públicos, de internação em hospitais, e muitos outros tipos de pedidos. A grande maioria desses pedidos era repassada por Salgado a parlamentares do partido, militantes que ocupavam cargos executivos ou aos diretórios regionais, solicitando encaminhamento favorável. ${ }^{16}$ A vasta documentação produzida e mantida organizada por Alberto Hoffmann, deputado estadual e federal pelo Rio Grande do Sul entre 1947 e 1982, reunindo mais de 60.000 correspondências trocadas com eleitores, comprova que o acompanhamento dos "assuntos pessoais" foi executado minuciosamente também em âmbito estadual, ao menos no Rio Grande do Sul. ${ }^{17}$

Mesmo buscando sistematicamente atender aos pedidos, Salgado manifestava contrariedade e desagrado com os pedidos feitos. Em uma carta, registrou "as aflições de espírito que me causam os companheiros de todo o Brasil reclamando empregos, empréstimos, promoções, transferências, bolsas de estudo, auxílios financeiros, que deixam-me num estado de depressão" (Correspondência de Plínio Salgado a Alexandre [nome incompleto], 15/2/1961 - APHRC-Pprp 61.02.15/1). Também o deputado perrepista Luis Compagnoni apelava aos partidários que não mais tomassem o tempo do

\footnotetext{
${ }^{15}$ Quando da posse do Secretário Nacional de Assuntos Pessoais, este número já teria chegado a 699 pedidos. Cf. Secretaria Nacional de Assuntos Pessoais. A Marcha, Rio de Janeiro, 17/4/1959, p. 4.

16 O fluxo de correspondências solicitando favores cresceu rapidamente a partir de 1950, quando o número de postos parlamentares e cargos executivos do partido cresceu. Em contrapartida, em 1948 um programa radiofônico proclamava:"Não existe em todo Brasil nenhum funcionário público nomeado ou apenas indicado por qualquer deputado ou vereador populista". Programa Radiofônico, sem data [1948] (CDAIBPRP). O termo populista era utilizado pelos integralistas para se referirem ao PRP.

7 A documentação foi constituída entre 1950 e 1990, no exercício dos mandatos como deputado estadual e deputado federal, e à frente das Secretárias da Agricultura, Economia e Finanças, e Interior, Desenvolvimento e Obras Públicas; e integra o acervo do CDAIBPRP.
} 
"Chefe" com assuntos pessoais, embora contraditoriamente registrasse que "a preocupação do PRP e do seu Chefe, neste setor, tem sido absoluta. Tudo o que lhe tem chegado às mãos, nosso Chefe tem encaminhado, mesmo com o sacrifício de suas atividades fundamentais" (COMPAGNONI, 1956, p. 3) O alegado "estado de depressão" de Salgado com a enxurrada de solicitações parece paradoxal, à primeira vista, pois é inegável que o próprio Salgado estimulava que os pedidos fossem feitos, assumindo uma posição paternal em relação aos militantes integralistas, mantendo e reforçando a relação estabelecida entre um "chefe" e seus chefiados. Mesmo as reclamações de Salgado eram parte da atitude paternal por ele assumida, inferiorizando e desqualificando seus "afilhados", ao mesmo tempo em que renovava sua fidelidade e subordinação. Outro aspecto que pode ser analisado a partir da estruturação de um serviço sistemático para o atendimento dos pedidos de favorecimentos pessoais é a forma como os integralistas se inseriam na ordem institucional vigente, não hesitando em utilizar-se da influência política para obtenção de vantagens, ao mesmo tempo em que denunciavam os "vícios" da democracia liberal e acusavam os demais partidos por se utilizarem de práticas semelhantes.

Um elemento que assumiu grande relevância no conjunto das atividades promovidas pelo PRP foi a mobilização em torno das convenções nacionais. Algumas delas, como a II Convenção Nacional (1946), a XII Convenção Nacional (1955) e o I Conclave Nacional do PRP (1957), foram utilizadas como momentos fundamentais de mobilização partidária e demonstração de força, reunindo alguns milhares de militantes e tendo os discursos de suas principais lideranças irradiados para todo o país. Com a II Convenção, os integralistas buscaram dar repercussão e festejar o retorno de Plínio Salgado ao país; a XII Convenção teve como objeto a homologação da candidatura presidencial de Plínio Salgado à eleição de 1955; e o Conclave de 1957 marcou os 25 anos do integralismo e aprovou o retorno do Sigma como símbolo partidário. De acordo com os estatutos do PRP, a Convenção deveria se realizar anualmente, constituída pelos membros do Diretório Nacional, do Conselho Nacional, presidentes dos diretórios estaduais, dos territórios e do Distrito Federal e pelos parlamentares do partido no Congresso Nacional (PRP, 1946). Desta forma, em princípio as convenções teriam dimensões reduzidas, com aproximadamente 80 delegados, mas em algumas convenções os presidentes dos diretórios estaduais eram acompanhados por numerosas delegações. As 
principais atribuições das convenções eram a eleição do Diretório Nacional e do Conselho Nacional, a reforma dos estatutos, a aprovação da candidatura presidencial, a aprovação de planos financeiros e de campanhas partidárias. A partir de 1956, alegando pretender "dar maior representação democrática às delegações", a reforma estatutária incluiu os presidentes dos diretórios municipais como delegados nas convenções nacionais, aumentando enormemente o número de possíveis delegados (SALGADO, 1956, p. 3 e 8). Com a centralização em torno do Gabinete da Presidência, havia pouco debate nas convenções, mantendo-se um rigoroso controle por parte do núcleo dirigente. A justificação do esvaziamento das convenções como espaço decisório encontra-se em uma correspondência de Plínio Salgado ao presidente do Diretório Regional do Rio Grande do Sul, Arno Arnt, em 1952, na qual sustentava que as decisões aparentemente políticas eram na realidade técnicas e, portanto, não deveriam ser objeto de deliberação política, devendo as convenções aprovar apenas "lineamentos gerais de problemas, sem aprovar conclusões particulares sobre matéria especializada” (Correspondência de Plínio Salgado ao Presidente do Diretório Regional do Rio Grande do Sul Arno Arnt, em 27/7/1952 - CDAIBPRP). Dentre os temas tidos como "técnicos", Salgado mencionava o debate em torno do estatuto do petróleo, a política cambial e o regime de governo, os quais eram em 1952 objetos de intensa mobilização política no país. A despolitização sob argumentação técnica levou à constituição de um Conselho Nacional de Estudos e Planos (CNEP), composto por 250 membros, nomeados e sob supervisão direta de Plínio Salgado. ${ }^{18}$ A posição do partido para estas questões passava então a seguir as conclusões das comissões componentes deste Conselho, saindo, portanto, do âmbito das convenções. Desta forma, não é de se estranhar que, mesmo nas convenções que reuniram maior público, as principais deliberações já eram antecipadamente conhecidas: a aprovação da candidatura de Plínio Salgado em 1955 se deu por aclamação, e o retorno do Sigma como símbolo partidário em 1957 foi antecipado em manchete principal pelo jornal partidário A Marcha 20 dias antes da realização do Conclave Nacional ("O sigma será o símbolo do PRP”. A Marcha, Rio de Janeiro, 5/7/1957, p. 1), o que evidencia a efetiva transformação da convenção em espaço e momento de demonstração de forças, em detrimento de qualquer debate efetivo.

18 No início de 1953, o CNEP já reuniria mais de 300 membros em 13 comissões e 72 subcomissões. Cf. "O Conselho Nacional de Estudos e Planos do PRP". A Marcha, Rio de Janeiro, 27/2/1953, p. 4. 


\section{O PRP como partido nacional}

A investigação acerca da distribuição regional da votação do PRP é importante para definir se é possível caracterizá-lo, no que se refere aos resultados eleitorais alcançados, como partido de âmbito nacional, tendo em vista que é recorrente na bibliografia especializada restringir a qualificação de partido nacional aos três principais partidos, afora o PCB em seu curto período legal. A despeito da exigência da legislação eleitoral de que os partidos fossem nacionais, vários partidos tinham a maior parte de sua votação concentrada em poucos estados ou mesmo em um único estado, como é o caso do PR (Minas Gerais), do PL (Rio Grande do Sul), do PRT e do PTN (São Paulo) e, em certa medida, do PSP (São Paulo). Gláucio Soares considera "discutível” a qualificação do PRP como partido nacional:

Inicialmente sua votação provinha basicamente de três estados: Rio Grande do Sul, São Paulo e Minas Gerais, que representavam aproximadamente 58\% do total. Mesmo não sendo um partido estadual, visto que dispunha de bases organizacionais extensas, sua base eleitoral era reduzida. Assim, é lícito concluir que, organizacionalmente, o período de 1945 a 1964 teve apenas seis partidos efetivamente nacionais - PSD, UDN e PCB, desde o início, e PTB, PSP e PRP, que construíram suas bases organizacionais. Entretanto, eleitoralmente, a qualificação do PSP e do PRP como partidos nacionais é discutível, devido à alta percentagem de seus votos oriunda de poucos estados. (SOARES, 2001, p. 60)

Esta avaliação obriga a uma investigação mais detalhada, tendo em vista que a qualificação do PRP como partido nacional é nossa principal hipótese. Um primeiro aspecto a se considerar é a representação que os próprios integrantes faziam do partido. Desde os primeiros anos, o discurso do PRP sempre atribuiu grande importância a seu "caráter nacional", em clara oposição às perspectivas regionalistas, como evidencia um programa radiofônico de 1948:

O Partido de Representação Popular não reconhece os direitos de paulistas, gaúchos, cearenses ou mineiros; ele reconhece apenas os direitos dos brasileiros. O Partido de Representação Popular não reconhece divisas de Estados, a não ser para fins administrativos, mas apenas as divisas do Brasil indivisível, como unidade política, econômica, étnica e geográfica. O Partido de Representação Popular é o único partido nacional, pois não depende de grupos e nem de interesses regionalistas. (Programa Radiofônico, 1948. CDAIBPRP) 
No que se refere aos dados eleitorais, sua investigação é dificultada pela forma de apresentação dos resultados nos Dados Estatísticos publicados pelo TSE (1964), pois no caso das coligações, não há identificação do partido a que pertence cada candidato, podendo-se identificar apenas o total obtido pela coligação. ${ }^{19}$ No caso do PRP, a dificuldade é ainda maior, pois em algumas situações ele apresentou candidatos na legenda de outros partidos, sem formalizar coligação, mediante acordo partidário. ${ }^{20}$ Para minimizar as distorções geradas por esses dois fatores, nosso procedimento metodológico foi o seguinte: a) trabalhar principalmente com os dados eleitorais para Assembleias Legislativas, tendo em vista que o número de coligações e acordos partidários neste âmbito foi inferior ao da Câmara dos Deputados, em virtude do coeficiente eleitoral ser menor; b) procurar identificar os candidatos apresentados em coligações e nas legendas de outros partidos, que pertencem ao PRP, mediante pesquisa nos jornais partidários A Marcha e Idade Nova, e à documentação partidária, e contabilizar os votos por eles recebidos; c) incluir os dados da eleição para a Câmara dos Deputados em 1945, na qual não ocorreram coligações e houve acordo partidário em apenas um estado, e os dados da eleição presidencial de 1955, na qual o PRP concorreu em chapa própria, através da candidatura presidencial de Plínio Salgado. Mesmo assim, ainda permanecem algumas pequenas lacunas, relativas às eleições de 1954, 1958 e 1962, em relação às quais não foi possível determinar com exatidão a votação obtida pelo PRP em alguns estados. Apesar dessas lacunas, os dados reunidos permitem uma visão geral de sua implantação nacional, reforçando sua qualificação como partido de âmbito nacional. Ao mesmo tempo, os dados eleitorais indicam que, embora tenha permanecido como pequeno partido, o PRP não foi eleitoralmente irrelevante. A votação obtida pelo PRP nos pleitos acima referidos encontra-se na Tabela 1 a seguir:

${ }^{19}$ Esta dificuldade é discutida por vários cientistas políticos, tendo inclusive induzido a equícovos. Por exemplo, o cientista político Olavo Brasil Lima Júnior contestou a tese clássica do declínio da votação dos partidos conservadores, sustentando que também os partidos trabalhistas declinavam e que apenas os pequenos partidos mantinham acelerada tendência ao crescimento, baseado na opção metodológica de atribuir aos pequenos partidos todas as cadeiras na Câmara dos Deputados de 1954 conquistadas por coligações, concluindo que detinham 38,7\% das cadeiras (LIMA JÚNIOR, 1983, p. 99), quando na realidade aqueles partidos efetivamente detinham apenas 9,6\%. Esta crítica encontra-se em Soares (1984, p. 99).

20 A relação estabelecida pelo PRP com os demais partidos nas diferentes conjunturas políticas em que atuou é discutida em Calil (2010) e em Cardoso (1999). 
Tabela 1 - Votação recebida pelo PRP por estado na eleição para Câmara Federal em 1945, nas eleições para Assembleias Legislativas em 1947, 1950 E 1954, na eleição presidencial de 1955 e nas eleições para Assembleias Legislativas em 1958 e 1962

\begin{tabular}{|c|c|c|c|c|c|c|c|}
\hline Estado/Eleição & 1945 & 1947 & 1950 & 1954 & 1955 & 1958 & 1962 \\
\hline Alagoas & - & 770 & 720 & 103 & 5.907 & 559 & 1.736 \\
\hline Amazonas & 700 & 649 & 882 & n.d..$^{*}$ & 3.648 & 1.302 & 2.417 \\
\hline Bahia & 13.173 & 8.381 & 23.028 & 22.517 & 63.136 & 25.123 & 32.105 \\
\hline Ceará & 3.144 & 6.753 & 7.603 & 2.891 & 13.408 & 13.523 & 28.153 \\
\hline $\begin{array}{c}\text { Distrito Federal / } \\
\text { Guanabara }\end{array}$ & 7.712 & 9.351 & 16.267 & 16.138 & 35.495 & 23.766 & 3.078 \\
\hline Espírito Santo & - & 6.430 & 8.523 & 10.023 & 29.531 & 17.640 & 18.704 \\
\hline Goiás & - & 344 & 3.836 & 3.413 & 3.732 & 918 & 3.375 \\
\hline Maranhão & - & 890 & 3.950 & 1.568 & 2.599 & n.d. & n.d. \\
\hline Mato Grosso & - & 596 & - & n.d. & 1.570 & 950 & n.d. \\
\hline Minas Gerais & 15.094 & 20.694 & 35.311 & 32.963 & 78.213 & 34.077 & 54.452 \\
\hline Pará & 996 & 1.589 & 1.777 & 725 & 4.213 & n.d. & 1.175 \\
\hline Paraíba & - & 583 & 614 & n.d. & 9.900 & 4.993 & 307 \\
\hline Paraná & 10.807 & 8.160 & 9.818 & 4.539 & 103.256 & 12.322 & 17.007 \\
\hline Pernambuco & 3.979 & 6.248 & 10.621 & 6.836 & 29.200 & 10.709 & 51.606 \\
\hline Piauí & - & 267 & n.d. & n.d. & 2.395 & 878 & 872 \\
\hline Rio de Janeiro & 8.884 & 8.269 & 10.887 & 4.831 & 27.683 & 9.620 & 10.076 \\
\hline $\begin{array}{l}\text { Rio Grande } \\
\text { do Norte }\end{array}$ & - & 1.041 & 2.984 & 829 & 13.888 & 2.255 & n.d. \\
\hline $\begin{array}{c}\text { Rio Grande } \\
\text { do Sul }\end{array}$ & 22.197 & 46.783 & 53.862 & 61.218 & 66.109 & 71.958 & 79.071 \\
\hline São Paulo & 39.543 & 25.344 & 35.937 & 89.722 & 159.051 & 140.247 & 164.460 \\
\hline Santa. Catarina & 8.771 & 7.230 & 16.059 & 9.803 & 59.162 & 18.314 & 27.477 \\
\hline Sergipe & - & - & - & - & 1.809 & 777 & n.d. \\
\hline Territórios & - & - & - & - & 474 & - & - \\
\hline Total Brasil $^{2^{* *}}$ & 133.990 & 160.372 & 242.679 & 265.168 & 714.379 & 378.979 & 468.703 \\
\hline
\end{tabular}

Fontes: TSE (1964); Idade Nova, Rio de Janeiro; A Marcha, Rio de Janeiro.

* Votação não determinada. 0 PRP participou com candidatos em coligação com outros partidos, ou com candidato apresentado por meio de outra legenda, mediante acordo partidário, mas não foi possível identificar seus candidatos ou a votação por eles recebida.

A avaliação dos resultados, considerados a partir dos números absolutos, indica um progressivo e constante crescimento dos resultados obtidos nas eleições parlamentares, com um acréscimo de $250 \%$ do total de votos recebidos na última eleição parlamentar disputada (1962) em relação à primeira (1945). Os resultados obtidos nas duas últimas eleições parlamentares só não 
são superiores aos obtidos na eleição presidencial de 1955. Esta, no entanto, mereceria um estudo à parte, pois claramente trata-se de uma votação que transcendeu os limites da estrutura partidária.

Tendo em vista que há igualmente um crescimento progressivo do eleitorado, torna-se necessário verificar se a tendência ao crescimento persiste quando se considera o percentual dos votos obtidos em relação ao total de votos válidos. Com este objetivo, a Tabela 2 indica o percentual obtido pelo PRP em relação ao total de votos válidos em cada pleito e a cada estado.

Os dados reunidos permitem algumas interpretações importantes. Percebe-se que a votação do PRP nas eleições parlamentares (portanto, não se considerando a eleição presidencial de 1955), mesmo em termos percentuais, cresceu de forma permanente, ainda que em patamares modestos, partindo dos 2,3\% obtidos em 1945 e chegando aos 3,8\% obtidos em 1962, um crescimento percentual de $65 \%$. Trata-se, sem dúvida, de uma votação modesta, mas que não pode ser considerada irrelevante, especialmente quando se considera que se trata de um partido ideológico e altamente hierarquizado, que sempre atuava de forma unificada. Os resultados obtidos na eleição presidencial de 1955 representam mais do que o dobro, em termos percentuais, ao obtido em qualquer votação parlamentar, inflacionando a média geral, que chega a 3,8\%. Considerando-se apenas as eleições parlamentares, a média geral foi de $3,1 \%$.

Em termos de implantação regional, verifica-se que o partido obteve uma média superior a 5\% em 4 estados: Espírito Santo (7,9\%), Rio Grande do Sul (6,8\%), Paraná (6,5\%) e Santa Catarina (5,9\%), não por coincidência os estados que reúnem o maior contingente de descendentes de alemães e italianos vivendo em regiões coloniais. ${ }^{21}$ Esses índices certamente conferiam uma importância grande ao PRP na vida política regional desses estados, tornando seu apoio decisivo em várias eleições para o governo estadual, o que inclusive permitiu ao PRP eleger o governador de Santa Catarina, em 1954. Em outros três estados, o PRP alcançou uma média entre 3,8\% e 5\%: Bahia (5,0\%), São Paulo (4,7\%) e Pernambuco (3,8\%), índice que ainda mantinha o partido como agente político relevante regionalmente. A votação

21 O perfil social dos dirigentes, filiados e eleitores do PRP é discutido em Calil (2005, p. 238-282). Parte expressiva dos eleitores do PRP era constituída de pequenos proprietários rurais de regiões de colonização alemã e italiana, o que também se expressava na composição social dos dirigentes em âmbito municipal. 
Tabela 2 - Percentual de votos obtidos pelo PRP em relação aos válidos por estado na eleição para Câmara Federal em 1945, nas eleições para Assembleias Legislativas em 1947, 1950 e 1954, na eleição presidencial de 1955 e nas eleições para Assembleias Legislativas em 1958 e 1962

\begin{tabular}{|c|c|c|c|c|c|c|c|c|}
\hline Estado/Eleição & 1945 & 1947 & 1950 & 1954 & 1955 & 1958 & 1962 & Média $^{3^{*}}$ \\
\hline Alagoas & - & $1,4 \%$ & $0,8 \%$ & $0,1 \%$ & $6,0 \%$ & $0,5 \%$ & $1,3 \%$ & $1,4 \%$ \\
\hline Amazonas & $3,2 \%$ & $2,8 \%$ & $2,0 \%$ & n.d. & $8,1 \%$ & $1,7 \%$ & $2,5 \%$ & $3,4 \%$ \\
\hline Bahia & $3,8 \%$ & $2,8 \%$ & $4,0 \%$ & $3,5 \%$ & $13,6 \%$ & $2,9 \%$ & $4,1 \%$ & $5,0 \%$ \\
\hline Ceará & $1,1 \%$ & $2,5 \%$ & $1,5 \%$ & $0,5 \%$ & $3,8 \%$ & $2,4 \%$ & $4,8 \%$ & $2,4 \%$ \\
\hline $\begin{array}{c}\text { DistritoFederal / } \\
\text { Guanabara }\end{array}$ & $1,6 \%$ & $2,2 \%$ & $2,9 \%$ & $2,4 \%$ & $5,2 \%$ & $2,6 \%$ & $0,3 \%$ & $2,5 \%$ \\
\hline Espírito Santo & - & $7,2 \%$ & $7,0 \%$ & $5,9 \%$ & $18,8 \%$ & $8 \%$ & $8,3 \%$ & $7,9 \%$ \\
\hline Goiás & - & $0,4 \%$ & $2,8 \%$ & $1,6 \%$ & $2,4 \%$ & $0,4 \%$ & $1 \%$ & $1,2 \%$ \\
\hline Maranhão & - & $1,2 \%$ & $2,7 \%$ & $0,8 \%$ & $1,8 \%$ & n.d. & n.d. & $1,3 \%$ \\
\hline Mato Grosso & - & $1,5 \%$ & - & n.d. & $1,6 \%$ & $0,6 \%$ & n.d. & $0,7 \%$ \\
\hline Minas Gerais & $1,5 \%$ & $2,5 \%$ & $2,8 \%$ & $2,3 \%$ & $6,4 \%$ & $1,8 \%$ & $3,1 \%$ & $2,9 \%$ \\
\hline Pará & $0,9 \%$ & $1,4 \%$ & $1,0 \%$ & $0,4 \%$ & $2,3 \%$ & n.d. & $0,5 \%$ & $1,0 \%$ \\
\hline Paraíba & - & $0,4 \%$ & $0,2 \%$ & n.d. & $4,5 \%$ & $1,9 \%$ & $0,1 \%$ & $1,2 \%$ \\
\hline Paraná & $5,8 \%$ & $6,1 \%$ & $3,8 \%$ & $1,1 \%$ & $24,0 \%$ & $2,1 \%$ & $2,3 \%$ & $6,5 \%$ \\
\hline Pernambuco & $1,5 \%$ & $2,6 \%$ & $2,8 \%$ & $1,6 \%$ & $6,8 \%$ & $2,0 \%$ & $9,3 \%$ & $3,8 \%$ \\
\hline Piauí & - & $0,3 \%$ & - & n.d. & $1,9 \%$ & $0,4 \%$ & $0,4 \%$ & $0,5 \%$ \\
\hline Rio de Janeiro & $2,8 \%$ & $3,1 \%$ & $2,6 \%$ & $0,9 \%$ & $5,9 \%$ & $1,3 \%$ & $1,3 \%$ & $2,6 \%$ \\
\hline $\begin{array}{c}\text { Rio Grande } \\
\text { do Norte }\end{array}$ & - & $0,9 \%$ & $1,8 \%$ & $0,4 \%$ & $9,8 \%$ & $1,2 \%$ & n.d. & $2,3 \%$ \\
\hline $\begin{array}{c}\text { Rio Grande } \\
\text { do Sul }\end{array}$ & $3,7 \%$ & $8,8 \%$ & $7,8 \%$ & $7,6 \%$ & $7,6 \%$ & $5,9 \%$ & $6,4 \%$ & $6,8 \%$ \\
\hline São Paulo & $3,0 \%$ & $2,3 \%$ & $2,6 \%$ & $4,9 \%$ & $8,4 \%$ & $5,2 \%$ & $6,3 \%$ & $4,7 \%$ \\
\hline Santa. Catarina & $4,5 \%$ & $4,1 \%$ & $2,7 \%$ & $3,1 \%$ & $17,5 \%$ & $3,7 \%$ & $5,4 \%$ & $5,9 \%$ \\
\hline Sergipe & - & - & - & - & $2,0 \%$ & $0,7 \%$ & n.d. & $0,5 \%$ \\
\hline Territórios & - & - & - & - & $2,2 \%$ & - & - & $0,3 \%$ \\
\hline Média Brasil $^{4^{* *}}$ & $2,3 \%$ & $3,4 \%$ & $3,1 \%$ & $2,8 \%$ & $8,3 \%$ & $3,2 \%$ & $3,8 \%$ & $3,8 \%$ \\
\hline
\end{tabular}

Fontes: TSE (1964); Idade Nova, Rio de Janeiro; A Marcha, Rio de Janeiro.

${ }^{*}$ A totalização relativa às eleições de 1954, 1958 e 1962 não inclui os estados cuja votação do PRP não foi possível determinar. Considerando-se que se trata na quase totalidade dos casos de estados com eleitorado mais reduzido, e nos quais o PRP tinha reduzida inserção eleitoral, é bastante provável que tal votação não chegasse a atingir $10 \%$ da votação total do partido naqueles pleitos.

** 0 cálculo da média por estado não levou em consideração as eleições em que se considera como votação não determinada, mas atribuiu $0 \%$ para os casos das eleições nas quais o PRP não participou.

*** A média por pleito, para eleições de 1954, 1958 e 1962, foi calculada em relação ao eleitorado total do país em cada eleição. Considerando-se que há seis casos relativos a 1954, seis casos relativos a 1958 e nove casos relativos a 1962, nos quais não foi possível determinar a votação, os índices aqui calculados para estes pleitos são levemente inferiores ao índice real alcançado pelo partido. Optou-se por não deixar de considerar os eleitores destes estados pelo fato de que em sua maioria são estados nos quais o PRP tinha votação abaixo da média nacional e, caso se tomasse este procedimento, 0 índice apresentado estaria inflacionado. 
do partido situou-se entre 2,3\% e 3,4\% em Amazonas (3,4\%), Minas Gerais (2,9\%), Rio de Janeiro (2,6\%), Distrito Federal / Guanabara (2,5\%), Ceará $(2,4 \%)$ e Rio Grande do Norte (2,3\%); e em outros cinco situou-se entre 1 e 1,4\%: Alagoas (1,4\%), Maranhão (1,3\%), Paraíba (1,2\%), Goiás (1,2\%) e Pará (1\%); o que não impediu o partido de ter alguma intervenção política regional nesses estados, embora em condições muito diversas, chegando a eleger prefeitos e vereadores em parte deles e a ter representação parlamentar estadual em alguns. Finalmente, em outros três estados e no conjunto dos territórios federais, o partido obteve resultados bastante inexpressivos: Mato Grosso (0,7\%), Piauí (0,5\%), Sergipe (0,5\%) e Territórios ( $0,3 \%)$, não se constituindo como força política relevante.

Também se observa que, junto ao Espírito Santo, foi nos três estados da região Sul que o partido obteve maior sucesso em termos relativos. Em termos absolutos, a relação se inverte em virtude do contingente eleitoral dos maiores colégios eleitorais (São Paulo e Minas Gerais), pertencentes à região Sudeste. A distribuição da votação do partido por região encontrase na Tabela 3:

Tabela 3 - Concentração da votação do PRP por região

\begin{tabular}{c|c|c|c|c|c|c|c|c}
\hline $\begin{array}{c}\text { Região/ } \\
\text { Eleição }\end{array}$ & $\mathbf{1 9 4 5}$ & $\mathbf{1 9 4 7}$ & $\mathbf{1 9 5 0}$ & $\mathbf{1 9 5 4}$ & $\mathbf{1 9 5 5}$ & $\mathbf{1 9 5 8}$ & $\mathbf{1 9 6 2}$ & Média \\
\hline Sudeste & $52,9 \%$ & $43,7 \%$ & $44 \%$ & $58 \%$ & $46,2 \%$ & $50,5 \%$ & $52,8 \%$ & 49,6 \\
\hline Sul & $30,9 \%$ & $38,8 \%$ & $32,9 \%$ & $28,5 \%$ & $32 \%$ & $25,4 \%$ & $26,4 \%$ & $30,7 \%$ \\
\hline Nordeste & $15 \%$ & $15,5 \%$ & $20,4 \%$ & $12,2 \%$ & $19,9 \%$ & $14,6 \%$ & $23,9 \%$ & $17,4 \%$ \\
\hline Norte & $1,2 \%$ & $1,4 \%$ & $1,1 \%$ & - & $1,1 \%$ & $0,3 \%$ & $0,8 \%$ & $0,7 \%$ \\
\hline $\begin{array}{c}\text { Centro } \\
\text { Oeste }\end{array}$ & - & $0,6 \%$ & $1,6 \%$ & $1,3 \%$ & $0,8 \%$ & $0,2 \%$ & - & $0,6 \%$ \\
\hline TOTAL & $100 \%$ & $100 \%$ & $100 \%$ & $100 \%$ & $100 \%$ & $100 \%$ & $100 \%$ & $100 \%$ \\
\hline
\end{tabular}

Fonte: Construída a partir da Tabela 2.

Novamente se verifica o padrão de distribuição da votação com concentração dos votos nas regiões Sul e Sudeste (chegando a $80 \%$ do total), com resultados mais modestos na região Nordeste e baixíssima implantação nas regiões Norte e Centro-Oeste. 
No que se refere às eleições municipais, os dados se encontram dispersos, sendo bastante difícil encontrar dados relativos à votação dos partidos. Apenas no que se refere ao estado do Rio Grande do Sul existem dados sistematizados relativos à votação do PRP, os quais evidenciam a importância das eleições de âmbito municipal para o partido e o elevado número de parlamentares eleitos, conforme se pode verificar a partir dos dados presentes na Tabela 4:

Tabela 4 - Prefeitos, Vice-Prefeitos e Vereadores do PRP eleitos no Rio Grande do Sul

\begin{tabular}{c|c|c|c|c|c|c}
\hline Eleição & $\mathbf{1 9 4 7}$ & $\mathbf{1 9 5 1}$ & $\mathbf{1 9 5 5}$ & $\mathbf{1 9 5 9}$ & $\mathbf{1 9 6 3}$ & Total \\
\hline Prefeitos eleitos & 3 & 3 & 5 & 13 & 8 & 32 \\
\hline $\begin{array}{c}\text { Vice-prefeitos eleitos } \\
\begin{array}{c}\text { Municípios com } \\
\text { vereadores do PRP }\end{array}\end{array}$ & 2 & 5 & 9 & 21 & 14 & 51 \\
\hline Total de vereadores & 57 & 50 & 70 & 69 & 71 & 317 \\
\hline
\end{tabular}

Fontes: CENTRO de Documentação sobre a Ação Integralista Brasileira e o PRP. Relação de prefeitos, vice-prefeitos e vereadores do PRP no Rio Grande do Sul (1947-1965). Porto Alegre: CDAIBPRP, 1997.

Estes dados permitem algumas observações importantes a respeito da implantação regional do partido naquele estado, destacando a gestão de diversas prefeituras, o expressivo número de vereadores eleitos no período e o fato de que, em algum momento, o PRP chegou a contar com representação parlamentar em grande parte dos municípios gaúchos. Certamente seria temerário generalizar os resultados obtidos em âmbito municipal no Rio Grande do Sul para outros estados. Ainda assim, de acordo com informações divulgadas nos jornais partidários, o PRP elegeu alguns prefeitos e inúmeros vereadores também em outros estados como Espírito Santo, Paraná, São Paulo, Bahia e Santa Catarina. Em algumas cidades, o PRP constituía-se como força majoritária, chegando a eleger a maior parte dos prefeitos e vereadores entre 1947 e 1963, como é o caso dos municípios de Castelo, Colatina, Santa Teresa (ES), Ijuí, Flores da Cunha, Nova Petrópolis e São Lourenço do Sul (RS). O partido ocupou também prefeituras de cidades de porte médio e grande importância regional, como Santo André, Suzano (SP), Novo Hamburgo e Caxias do Sul (RS). ${ }^{22}$

22 Em 1964, o PRP também esteve à frente da prefeitura de Salvador, mas não obteve o posto através de eleição. Nelson de Souza foi nomeado interventor pela ditadura, substituindo o prefeito cassado. 
O PRP elegeu, no decorrer de sua existência, um total de 26 deputados federais e 97 deputados estaduais, distribuídos em 15 estados e no Distrito Federal, o que revela que esteve presente no debate político da maior parte do território nacional. A Tabela 5 apresenta de forma detalhada a distribuição dessa representação por estado, a cada eleição:

Tabela 5 - Deputados Federais e Estaduais eleitos pelo PRP, por estado

\begin{tabular}{c|c|c|c|c|c|c|c|c|c|c|c|c}
\hline & \multicolumn{3}{|c|}{ Bancada de Deputados Federais } & \multicolumn{5}{c}{ Bancada de Deputados Estaduais } \\
\hline Eleição & 1945 & $\mathbf{1 9 5 0}$ & $\mathbf{1 9 5 4}$ & $\mathbf{1 9 5 8}$ & $\mathbf{1 9 6 2}$ & Total & $\mathbf{1 9 4 7}$ & $\mathbf{1 9 5 0}$ & $\mathbf{1 9 5 4}$ & $\mathbf{1 9 5 8}$ & $\mathbf{1 9 6 2}$ & Total \\
\hline Bahia & - & - & 1 & 1 & 1 & 3 & 1 & 2 & 2 & 2 & 2 & 9 \\
\hline Ceará & - & - & - & - & - & - & 1 & - & - & 1 & 3 & 5 \\
\hline $\begin{array}{c}\text { Distrito } \\
\text { Federal / } \\
\text { Guanabara }\end{array}$ & - & - & 1 & - & - & 1 & 1 & 1 & 1 & 1 & - & 4 \\
\hline $\begin{array}{c}\text { Espírito } \\
\text { Santo }\end{array}$ & - & 1 & 1 & 1 & 1 & 4 & 2 & 2 & 2 & 2 & 3 & 11 \\
\hline Goiás & - & - & - & - & - & - & - & - & 1 & - & - & 1 \\
\hline Mato Grosso & - & - & - & - & - & - & 1 & - & - & - & - & 1 \\
\hline Maranhão & - & - & - & - & - & - & 1 & - & - & - & - & 1 \\
\hline Minas Gerais & - & - & - & - & 1 & 1 & 1 & 2 & 1 & 1 & 2 & 7 \\
\hline Paraná & - & - & - & 1 & 1 & 2 & 2 & 1 & 1 & 1 & 2 & 7 \\
\hline Pernambuco & - & - & - & - & - & - & 1 & 1 & - & 1 & 6 & 9 \\
\hline Piauí & - & - & 1 & - & - & 1 & - & - & - & - & - & - \\
\hline $\begin{array}{c}\text { Rio de } \\
\text { Janeiro }\end{array}$ & - & - & 1 & - & - & 1 & 1 & 1 & - & - & - & 2 \\
\hline $\begin{array}{c}\text { Rio Grande } \\
\text { do Sul }\end{array}$ & - & 1 & 2 & 2 & 2 & 7 & 4 & 4 & 4 & 3 & 3 & 18 \\
\hline São Paulo & 1 & - & 1 & - & 1 & 3 & 1 & 2 & 3 & 5 & 7 & 18 \\
\hline $\begin{array}{c}\text { Santa. } \\
\text { Catarina }\end{array}$ & - & 1 & 1 & 1 & - & 3 & 1 & 3 & 1 & - & 2 & 6 \\
\hline Total & 1 & 3 & 9 & 6 & 7 & 26 & 18 & 19 & 16 & 17 & 30 & 97 \\
\hline
\end{tabular}

Fontes: TSE (1964); Idade Nova, Rio de Janeiro; A Marcha, Rio de Janeiro.

Estes dados indicam que o PRP elegeu ao menos um parlamentar na maior parte dos estados (71\%), cabendo destacar ainda que os estados em que não logrou êxito situam-se nas regiões Norte (Amazonas e Pará) e Nor- 
deste (Alagoas, Paraíba, Rio Grande do Norte, Sergipe) e não se encontravam entre os estados considerados como politicamente mais relevantes. Também se evidencia que $76 \%$ dos 123 parlamentares eleitos eram provenientes das regiões Sudeste e Sul: respectivamente 50 e 43 parlamentares (41\% e 35\% do total). Outros 28 parlamentares (22,5\%) eram provenientes do Nordeste, em especial Bahia e Pernambuco. Por outro lado, apenas dois parlamentares eram da região Centro-Oeste (1,5\%), e nenhum da região Norte. Evidenciase, assim, uma clara concentração nas regiões Sul e Sudeste, complementada por razoável inserção nos principais estados do Nordeste.

Finalmente, cabe avaliar em que medida a ressalva feita por Gláucio Soares impede ou fragiliza a qualificação do PRP como partido nacional. De acordo com ele, a votação do PRP se concentrou basicamente em três estados. É necessário reconhecer que o índice por ele apontado (58\% em 1947) como expressivo da parcela de votos partidários obtidos em três estado está correto, mas é possível avaliar esse dado em uma perspectiva mais ampla. Para tanto, indicamos a cada processo eleitoral o percentual em relação à votação total do partido que perfaz a votação em três situações: considerando apenas o estado onde o PRP obteve maior número de votos, considerando os três estados primeiros e considerando os cinco primeiro, como se evidencia na Tabela 6:

Tabela 6 - Concentração da votação do PRP (percentagem dos votos recebidos no estado onde recebeu maior votação absoluta; nos três estados; e nos cinco estados)

\begin{tabular}{c|c|c|c|c|c|c|c|c}
\hline Eleição & 1945 & 1947 & 1950 & 1954 & 1955 & 1958 & 1962 & Média \\
\hline Estado maior votação & $29,5 \%$ & $29,1 \%$ & $22,2 \%$ & $33,8 \%$ & $22,3 \%$ & $37 \%$ & $35 \%$ & $29,8 \%$ \\
\hline 3 estados maior votação & $57,3 \%$ & $57,9 \%$ & $51,6 \%$ & $69,3 \%$ & $47,7 \%$ & $65 \%$ & $63,6 \%$ & $58,9 \%$ \\
\hline 5 estados maior votação & $75,2 \%$ & $68,9 \%$ & $67,7 \%$ & $83,9 \%$ & $65,7 \%$ & $77,9 \%$ & $81,4 \%$ & $74,4 \%$ \\
\hline
\end{tabular}

Fonte: Construída a partir da Tabela 1.

Percebe-se, desta forma, que para o conjunto do período o PRP obteve em três estados quase $60 \%$ de sua votação, o que parece reforçar o argumento de Soares. No entanto, é necessário lembrar que o eleitorado destes mesmos três estados (São Paulo, Minas Gerais e Rio Grande do Sul) representava, 
em 1947, 49,1\% do total de votantes daquela eleição, índice que se manteve relativamente estável até 1962 , quando atingia 44,1\%. Portanto, embora seja necessário reconhecer que há alguma concentração de votos nesses estados, a distorção existente é bem menor do que parece à primeira vista, e é explicável pelo perfil do partido e pela dificuldade de penetração nos estados economicamente mais atrasados, nos quais a maior parte do eleitorado permanecia controlada pelos PSD e pela UDN através de práticas coronelistas. Igualmente o crescimento do índice relativo ao estado com maior votação nas eleições de 1958 e 1962, é explicável pelo avanço do PRP em São Paulo, maior colégio eleitoral do país. É certo que o PRP se ressentia de uma estruturação bastante frágil nas regiões Norte e Centro-Oeste e em alguns estados do Nordeste e que a distribuição da votação do PRP não era completamente homogênea no conjunto do país - como de resto a de nenhum outro partido o foi - mas há diversos elementos que permitem sustentar a qualificação do PRP como partido de âmbito nacional: sua estruturação na totalidade dos estados; a eleição de pelo menos um deputado em 16 estados (incluindo Guanabara, que era Distrito Federal até 1960); e a presença efetiva no debate político nacional e nos principais estados.

\section{Considerações finais}

A discussão aqui apresentada buscou avaliar a trajetória do PRP entre 1945 e 1965, considerando as características e peculiaridades de sua estrutura organizativa e, concomitantemente, os resultados eleitorais obtidos, de forma a avaliar adequadamente sua caracterização como partido nacional. Neste sentido, é importante considerar a articulação entre ambos os aspectos, tendo em vista que um partido com as características do PRP - constituído de forma centralizada e hierárquica e com uma estrutura organizativa que não visava exclusivamente àa participação em processos eleitorais - diferencia-se claramente dos principais partidos políticos, como o PSD e a UDN. Enquanto estes partidos eram organizados a partir de interesses sociais e econômicos dominantes, com vistas ao gerenciamento da máquina estatal, representando diferentes frações da classe dominante no controle do aparelho estatal (executivo e legislativo) e, portanto, contando com uma estrutura interna flexível e essencialmente voltada à ocupação de posições de poder no interior do aparelho de Estado, o PRP desempenhava um papel mediato, assumindo tarefas de médio e longo prazo, como a sistemática propagação 
do anticomunismo e a permanente afirmação de uma concepção excludente de democracia. Em vista disto, acreditamos que não é correto dimensionar a importância da intervenção do PRP tomando por base exclusiva os resultados eleitorais por ele obtidos. Ainda assim, os próprios resultados eleitorais obtidos não podem ser considerados irrelevantes, devendo-se considerar que: a) a votação recebida pelo PRP era bastante estável, com forte tendência ao crescimento em termos absolutos e moderada elevação em termos percentuais; b) o partido se fazia presente na quase totalidade dos estados na maior parte dos pleitos; c) foram eleitos deputados do PRP na maioria das unidades federativas; d) os resultados eleitorais obtidos em âmbito municipal, ainda que não tenham sido detalhadamente investigados, indicam a presença parlamentar do PRP em grande número de municípios e algumas situações em que ele chegou à condição de partido majoritário; e) nos pleitos estaduais majoritários, o contingente eleitoral que o partido detinha era muitas vezes decisivo em processos eleitorais fortemente polarizados, permitindo que o partido obtivesse importantes compensações para o estabelecimento de alianças e coligações; e f) a votação nacionalmente recebida pelo PRP não era oriunda de poucos estados - ao contrário, correspondia à expansão de sua estrutura organizativa, possibilitando uma clara inserção nacional do partido.

O PRP se constituiu e se manteve durante toda sua trajetória como partido de âmbito nacional com forte teor ideológico, centrado na oposição ao comunismo, na defesa da restrição das margens do exercício democrático, na defesa da propriedade privada e do corporativismo e na disseminação de concepções hierárquicas, elitistas e excludentes. Desempenhou, certamente, papel específico, ainda que muitas vezes complementar e articulado às principais forças políticas conservadoras e autoritárias, como a UDN e o PSD. Consideramos, desta forma, integralmente justificada sua caracterização como partido nacional, com personalidade própria e implantação na maior parte do país.

\section{Arquivos e fontes consultados}

A) Arquivo Público e Histórico de Rio Claro (Rua 8, no 3300 - Alto de Santana - Rio Claro - SP). Fundo Plínio Salgado: Constituído por 150 caixas, reúne a documentação política de Plínio Salgado das décadas de 1920 a 1970. Inclui a documentação do Gabinete da Presidência do Diretório Nacional 
do PRP (1946-1965), documentos referentes às secretarias nacionais do PRP, manuscritos, originais de entrevistas concedidas por Plínio Salgado, panfletos, folhetos, revistas, livros de atas, listas de presenças, originais de discursos e programas radiofônicos, relatórios do serviço secreto integralista, recortes de jornais, relatórios dos diretórios regionais do PRP, iconografia, abaixo-assinados, balancetes financeiros e manifestos. Correspondência de Plínio Salgado: Abrange toda a correspondência particular e política, enviada e expedida por Plínio Salgado.

B) Centro de Documentação sobre a Ação Integralista Brasileira e o PRP (Rua Coronel Vicente 520 cj. 2 - Centro - Porto Alegre - SP). Fundos Documentais: Deliberações do Diretório Nacional; Correspondências do Diretório Nacional ao Diretório Regional; Correspondências do Diretório Regional ao Diretório Nacional; Correspondências da Secretaria Nacional de Propaganda; Documentação da Secretaria do Diretório Regional do PRP-RS; Livros de Atas das Convenções do PRP do Rio Grande do Sul; Documentação dos processos eleitorais; Estatutos e Regulamentos do PRP; Panfletos eleitorais e doutrinários; Recortes de jornais; Programas radiofônicos; Jornais A Marcha; Idade Nova; Reação Brasileira e Boletim do PRP.

\section{Referências bibliográficas}

CALIL, Gilberto. 2001. O integralismo no pós-guerra: a formação do PRP (1945-1950). Porto Alegre: PUCRS.

. 2005a. O integralismo no processo político brasileiro: o PRP entre 1945 e 1965 - cães de guarda da ordem burguesa. Tese de doutorado. Niterói: UFF.

.2005b. “Os integralistas e o golpe militar de 1964”. História \& Luta de Classes, n. 1, p. 55-76.

. 2010. Integralismo e hegemonia burguesa: a intervenção do PRP na política brasileira (1945-1965). Cascavel: Edunioeste (Coleção Tempos Históricos, 8).

CARDOSO, Claudira. 1999. Partido de Representação Popular: política de alianças e participação nos governos estaduais do Rio Grande do Sul de 1958 e 1962. Dissertação de Mestrado. Porto Alegre: PUCRS.

. 2009. O integralismo no processo político gaúcho: a máquina 
partidária do PRP e seus dirigentes (1945-1965). Tese de Doutorado. Porto Alegre: UFRGS.

CARNEIRO, Márcia Regina. 2007. Do Sigma ao Sigma - entre a anta, a águia, o leão e o galo - a construção de memórias integralistas. Tese de Doutorado. Niterói: UFF.

CARONE, Edgard. 1985. A república liberal: instituições e classes sociais (1945-1964). Vol. 1. São Paulo: Difel. (Coleção Corpo e Alma do Brasil). CAVALARI, Rosa. 1999. Integralismo: ideologia e organização de um partido de massa no Brasil (1932-1937). Bauru: Edusc.

CHASIN, José. 1999. O integralismo de Plínio Salgado: forma de regressividade no capitalismo hiper-tardio. $2^{a}$ ed. São Paulo: Ad Hominen.

CHAUÍ, Marilena. 1978. "Apontamentos para uma crítica da Ação Integralista Brasileira”. In: CHAUÍ, Marilena \& FRANCO, Maria Sylvia Carvalho. Ideologia e mobilização popular. Rio de Janeiro: CEDEC / Paz e Terra.

COMPAGNONI, Luis. 1956. "A chaga do empreguismo". A Marcha, Rio de Janeiro, 27 de abril.

DUVERGER, Maurice. 1970. Os partidos políticos. Rio de Janeiro: Zahar.

LIMA JÚNIOR, Olavo Brasil de. 1983. Os partidos políticos brasileiros: a experiência federal e regional. 1945-1964. Rio de Janeiro: Graal.

PRP - PARTIDO DE REPRESENTAÇÃO POPULAR. 1945. Programa e Estatutos do Partido de Representação Popular. Rio de Janeiro: Partido de Representação Popular.

. 1946. Estatutos. Aprovados pela II Convenção Nacional (Mimeografado).

. 1947. Estatutos. Aprovados pela III Convenção Nacional (Mimeografado). . 1948. Regulamento da Secretaria Nacional de Arregimentação de Marítimos. Rio de Janeiro: Vanguarda.

. 1959. Estatutos. Aprovados pela XIII Convenção Nacional (Mimeografado).

. 1961. Estatutos. Aprovados pela XVI Convenção Nacional (Mimeografado).

. 1962. Estatutos. Aprovados pela XIX Convenção Nacional (Mimeografado).

SALGADO, Plínio. 1956. "Ergueu-se uma nova força”. A Marcha, Rio de Janeiro, 27 de abril. 
SECRETARIA NACIONAL DE ARREGIMENTAÇÃO DE ESTUDANTES. s./d. Organização (Mimeografado).

SECRETARIA NACIONAL DE ARREGIMENTAÇÃO ELEITORAL. s./d. Organização (Mimeografado).

SECRETARIA NACIONAL DE ASSITÊNCIA SOCIAL. s./d. Organização (Mimeografado).

SECRETARIA NACIONAL DE EDUCAÇÃO MORAL, CÍVICA E FÍSICA. s./d. Organização (Mimeografado).

SOARES, Gláucio Ary Dillon. 1984. "Uma resenha e uma resposta”. Dados, v. 27, n. 1, p. 93-104. . 2001. A democracia interrompida. Rio de Janeiro: FGV.

TRIBUNAL SUPERIOR ELEITORAL - TSE. 1964. Dados estatísticos. Brasília: Imprensa Oficial, 9 vols.

TRINDADE, Hélgio. 1974. Integralismo: o fascismo brasileiro na década de 30. São Paulo/Porto Alegre: Difel/UFRGS (Coleção “Corpo e Alma do Brasil").

VASCONCELOS, Gilberto. 1979. A ideologia curupira: análise do discurso integralista. São Paulo: Brasiliense.

\section{Resumo}

A proposta deste artigo é discutir a estruturação do Partido de Representação Popular entre 1945 e 1965, com destaque para sua organização interna e sua inserção eleitoral. A hipótese principal é que esse partido efetivamente configurou-se como partido de âmbito nacional de caráter anticomunista, antidemocrático e fascistizante. São analisados dados relativos à estruturação dos diretórios partidários, em âmbito municipal e estadual, à expansão de sua estrutura organizacional ao longo do período e aos resultados eleitorais obtidos. Com base nestes dados, é possível concluir que esse partido efetivamente atingiu uma estruturação nacional, tanto em termos organizativos como no que se refere aos resultados eleitorais obtidos, embora parte expressiva de sua votação tenha se mantido concentrada nos estados mais desenvolvidos e populosos.

Palavras-chave: integralismo; Partido de Representação Popular; partido político; política brasileira 1945-1965; Plínio Salgado.

\section{Abstract}

The purpose of this paper is to discuss the structuring of the Partido de Representação Popular [Popular Representation Party] between 1945 and 1965, with emphasis on its internal organization and its election insertion. The main hypothesis is that the party 
effectively configured as a national party of anti-communist, anti-democratic and fascist character. Data on the structure of its party directories at municipal and state levels are analyzed, as well as information on the expansion of its organizational structure over the period, and the election results it obtained. Based on these data and analyses, it is possible to conclude that the party actually reached a national structure, both in organizational terms and in relation to the electoral results obtained, although a significant proportion of its vote has remained concentrated in the most developed and populous states.

Key words: integralism; Partido de Representação Popular; political party; Brazilian politics 1945-1965; Plínio Salgado.

Recebido em abril de 2010.

Aprovado em setembro de 2010. 